Kazimierz Michalerwski*

\title{
Autoprezentacja i prezentacja w mediach
}

W różnych sytuacjach przedstawiamy się interlokutorom, adresatom komunikatów. $Z$ rozmysłem i bezwiednie. I wtedy, kiedy nawiązuje się nowy kontakt, i wtedy, kiedy się kontakt odnawia. W komunikacji publicznej i również rodzinnej, koleżeńskiej, co wydaje się nie dość uświadamiane. Chociaż wcześniejsze więzi ułatwiają przywołanie gotowości odbiorcy do życzliwego reagowania na kolejne przekazywane mu przez tę samą osobę komunikaty, to nie można wykluczyć, że pojawi się jakieś zakłócenie - powód zniechęcenia. Przypadków negatywnych zmian w relacjach koleżeńskich, przyjacielskich, a nawet rodzinnych można znaleźć wiele. Złe dotychczasowe kontakty udaje się też niekiedy poprawić. Można uznać, że każde wystąpienie prywatne i publiczne ma moc kształtowania, podtrzymywania i ewentualnie modyfikowania (polepszania albo pogarszania) relacji. Wystąpienia często eksponują pozytywne cechy nadawcy ${ }^{1}$, ale zdarzają się i niefortunne, ukazujące jego niedostatki. Wiele w kontaktach między ludźmi zależy, oczywiście, od różnorodnych czynników wykraczających zdecydowanie poza sam proces komunikowania się, ale też zastosowane doraźnie (werbalne i niewerbalne) środki mają na ich kształt niewątpliwy wpływ. Wśród nich są te, które warunkują wstępne pozyskiwanie życzliwości rozmówcy.

Spotyka się publikacje zawierające stosowne instrukcje dotyczące autokreacji, warto jednak przyjrzeć się rzeczywistym ludzkim zachowaniom, których skutkiem jest kształtowanie obrazu nadawcy w opinii odbiorcy.

" Prof. zw. dr hab. Kazimierz Michalewski - Uniwersytet Łódzki, Wydział Filologiczny, Katedra Współczesnego Języka Polskiego, al. Kościuszki 65, 90-514 Łódź.

${ }^{1}$ Skłonność do autoprezentacji, do kształtowania pozytywnego obrazu siebie objawiana jest dość powszechnie. Por.: Z punktu widzenia autocharakterystyki postaci uderza ogromna przewaga wskazań pozytywnych nad negatywnymi (H. Zgółkowa, Stownictwo w autokreacji, [w:] K. Michalewski (red.), Wspótczesna leksyka, t. 2, Łódź 2001, s. 206, 208). 
Obserwować i opisywać można autoprezentację w kontaktach bezpośrednich, rodzinnych, koleżeńskich, przyjacielskich, ale łatwiej o wiarygodne uogólnienia na podstawie znanych powszechnie przykładów medialnych. $\mathrm{Z}$ pewnymi uzupełnieniami można je odnieść do codziennych, prywatnych relacji.

W kontaktach bezpośrednich ważne są wszystkie składniki komunikatów - werbalne z cechami prozodycznymi, wizualne (wyraz twarzy - mimika, strój, posturyka, gestykulacja, proksemika), haptyczne (uściski dłoni, dotknięcia ramion, twarzy), olfaktoryczne (świeży oddech, subtelna woń dezodorantu, wody kolońskiej). Od wyboru środków zależy nie tylko pierwsze wrażenie, ale i dalsze podtrzymywanie życzliwej uwagi partnera. Wybór stosowny powinien być obliczony na przewidywane upodobania odbiorcy i cel nawiązywania (utrzymywania) kontaktów z nim. Nie znaczy to wcale, że zawsze fortunne mają być oznaki szczególnej elegancji i świadectwa dostatku, atrakcyjności osobistej.

W kontaktach za pośrednictwem mediów wykorzystuje się tylko część środków komunikowania się. W radiu wyzyskiwane są werbalne i paralingwistyczne; w telewizji pokazuje się twarz, strój, gestykuluje się i odpowiednio wypowiada tekst. $\mathrm{W}$ prasie przedstawia się tekst $\mathrm{z}$ obieranymi przez pośrednika - dziennikarza - cechami graficznymi, barwnymi i ewentualnie ikonicznymi. O całości formy prasowej decyduje nadawca tylko w przypadku ogłoszeń płatnych.

Wyraziste są dwa rodzaje medialnych autoprezentacji: wystąpienia osób publicznych (głównie polityków) i anonse matrymonialne. W obu sytuacjach nadawca stara się o zapewnienie sobie aprobaty odbiorców. Wprawdzie ogłoszenie matrymonialne ma ułatwić znalezienie kandydata na małżonka, ale jego autor oczekuje zwykle licznych reakcji, wielu zgłoszeń. Reklamujący się polityk - kandydat do funkcji publicznej - również stara się zainteresować swoją ofertą możliwie największą liczbę osób. Inaczej niż większość autorów anonsów, stara się nie tylko o jednorazową aprobatę, ale też o jej podtrzymywanie. Do następnej kampanii wyborczej.

Nadawca ma w obu sytuacjach nadzieję na poprawę swojego samopoczucia, prestiżu społecznego, sytuacji materialnej. Korzyści finansowe i emocjonalne są, jak się bardzo często okazuje, bardzo istotne ${ }^{2}$. Można się spodziewać, że właściwie tylko w ogłoszeniach matrymonialnych pojawiają się informacje o stanie zdrowia i sprawności fizycznej kandydatów, jednak i dla wyborców te cechy stają się coraz ważniejsze.

2 Por.: Przystojny, wyksztatcony szuka niezależnej fnansowo partnerki, mile widziany wtasny dom $i$ samochód. 
Ogłoszenia matrymonialne spotyka się dotąd przede wszystkim w gazetach codziennych ${ }^{3}$, zaś materiały (spoty) przedwyborcze znaleźć można także poza nimi - w ulotkach, na plakatach, bilbordach. Usłyszeć je można w radiu i obejrzeć w telewizji. Najskuteczniejsze wydają się kampanie telewizyjne, bo te (w odróżnieniu od gazetowych) docierają do odbiorcy bez jego woli, a oddziałują wieloma środkami wizualnymi i akustycznymi. Prezentujący się w różnych sytuacjach (także w trakcie bezpośrednich spotkań z wyborcami) polityk wykorzystuje różnorodne środki akustyczne, wizualne, olfaktoryczne, haptyczne, proksemiczne, z których osoba poszukująca partnera może korzystać w kontakcie bezpośrednim jako zalotnik, ale nie jako autor matrymonialnego anonsu. Porównywać można zatem przede wszystkim teksty reklam obu rodzajów.

Autor ogłoszenia matrymonialnego ma wpływ wyłącznie na dobór słów, zestawienie ich $\mathrm{w}$ grupy wyrazowe i wypowiedzenia. Redakcja gazety standaryzuje graficzną postać inseratów, a więc decyduje o kształcie i wielkości czcionki, długości wersów, o odstępach między wyrazami i wersami, o wyborze strony i miejsca na stronie itd. Zdarza się, że narzuca również konstrukcję składniową (np. tytułem działu: Poznam). Wyjątkowo zamieszczane są fotografie ogłoszeniodawców. Ograniczenia nakładane przez redakcje na autorów inseratów utrudniają porównywanie ich tekstów z autentycznymi (przynajmniej autoryzowanymi) i bogatszymi formalnie (choćby o środki paralingwistyczne) tekstami polityków, znanych już zwykle z licznych wcześniejszych wystąpień prezentowanych we wszystkich rodzajach mediów. Nawet porównywanie słownictwa staje się kłopotliwe, kiedy np. nie wiemy, z jaką intonacją byłby wymówiony napisany wyraz. Konfrontację tekstów można zatem przedstawić wyłącznie $\mathrm{z}$ wynikającymi $\mathrm{z}$ takich powodów zastrzeżeniami, chociaż trzeba dostrzec możliwość ingerencji redakcji gazet, radia, telewizji również w autoprezentacyjne zabiegi polityków.

Orzeczenia wyrażane formami 1. osoby liczby pojedynczej czasownika występują wcale nie wyjątkowo w tekstach kampanii wyborczej, bo służą eksponowaniu konkretnych polityków, np.: Jestem perfekcjonistą. Czuje się cztowiekiem bardzo przyzwoitym. Zdarza się łączenie ich z zaimkiem ja, np.: [...] ja mam swobodę rozmowy z ludżmi [...]. Politycy mówią też o sobie, łącząc w innej niż podmiot funkcji formy zależne zaimka ja, np.: [...] ludzie lubiq ze mnq rozmawiać [...] oraz zaimka dzierżawczego mój, np.: Sondaże dotyczace popularności polityków wskazywaty na wysoki wzrost mojej popularnosci. Niekiedy czynią swoje imiona podmiotami zdań z orzeczeniem w formie

${ }^{3}$ Zdarzały się też programy telewizyjne poświęcone swataniu osób samotnych. Inseraty pojawiają się również w Internecie. 
3. osoby liczby pojedynczej, np.: Lepper może i ma rację, mówi dobrze, pokazuje źródta pieniędzy [...], Za rzq̨ów Józefa Oleksego tempo wzrostu PKB byto 7\%, a bezrobocie byto 2 miliony mniejsze niż w tej chwili; Alicja potrafi. Zdaje się niekiedy, że politycy jednej partii stanowią zespół zainteresowany wspólnym sukcesem. Pozór solidarności zespołowej jest o tyle ważny, że materiały agitacyjne, w odróżnieniu od anonsów matrymonialnych, zawierają zdania z orzeczeniami w formach liczby mnogiej. Najczęściej oczywiście stosują formy 1. osoby liczby mnogiej, kiedy występują w imieniu partii, ugrupowania, np.: Chcemy, żeby państwo byto [...] uczciwe, tanie skuteczne [...], i wtedy, kiedy eksponują swoje powiązanie z wyborcą, np.: Budujmy razem NASZ DOM spokojny i bezpieczny. Jesteśmy razem, wygramy razem. Używają zaimków my, nasz, swój, np.: [...] coraz więcej ludzi przytacza się do nas [...], Nasze poparcie wzrasta [...], Potrzeba czasu, żeby ustalić swojq wiarygodnośc [...].

W ogłoszeniach matrymonialnych występują podobne konstrukcje składniowe, a więc wypowiedzenia eksplicite ingracjacyjne $z$ formami 1. osoby liczby pojedynczej, np.: Jestem atrakcyjnq blondynkq [...], pośrednio ingracjacyjne ( $\mathrm{z}$ prezentowanymi oczekiwaniami godnymi uznania nadawcy) z takimi samymi formami, np.: Szukam dziewczyny, dla której mitośc i przyjaźń nie sq pustymi stowami [...]; znacznie częściej ogłoszeniodawcy prezentują swoje zalety $\mathrm{w}$ wypowiedzeniach $\mathrm{z}$ orzeczeniem $\mathrm{w}$ formie 3. osoby liczby pojedynczej, np.: Wolna 46/160 zadbana, pozna przystojnego o podobnych cechach; Wdowiec (58), wyższe, solidny, męski, samochód, pozna wdowe niepalaca, zgrabna; Wolny 58 lat zrównoważony, bez zobowiquań, niezależny finansowo, pozna mita, atrakcyjnq. Niekiedy wykorzystują również orzeczenia w innych formach i wtedy zaimki ja, mój czynią składnikami zdań innymi niż podmiot, np.: Daj mi to miejsce przy sobie! Wolna, co bardzo przypomina częste apele Gtosuj na mnie!

$\mathrm{W}$ inseratach mogą się pojawiać wypowiedzenia $\mathrm{z}$ orzeczeniem $\mathrm{w}$ formie 1. osoby liczby mnogiej, takie jak przedwyborcze, ale tylko wtedy, kiedy nadawca włącza odbiorcę jako potencjalnego współsprawcę (potencjalnego partnera), np.: Razem możemy przejśc przez życie wspierając się w zdrowiu $i$ chorobie, radościach $i$ smutkach, nie zaś społeczność, w której imieniu miałby występować autor.

W tekstach propagandowych zdarzają się również konstrukcje składniowe służące zakamuflowanej, aluzyjnej ingracjacji. Eksponowane są, jak się trzeba domyślać, cenne cechy właściwe nadawcy, np.: W tym rzqdzie nie szanowano osób, które ciężko pracuja, sq sprawni (!) intelektualnie, sq kompetentni, [...] bez wrażliwości w tej chwili nie da się odnosić tych sukcesów. To, co jest niezbędne w polityce, to jest poczucie stǘby. Autor ogłoszenia podobnie może apelować do wyobraźni odbiorcy, np.: Nigdy na to nie miatem czasu - kawaler 36/177. 
Jednym ze stosowanych zabiegów jest minoderyczne pozorowanie autoprezentacji negatywnej, np.: Kiedy sie nie zrealizowata pewna koncepcja, statem się więzniem tej koncepcji. Nie potrafitem, przegratem, nie uporatem sie z wtasna partia; Ja jako Lepper nie uważam się za alfe i omege, wszechwiedzacy nie jestem, absolutnie [...]. W anonsach podobnie, np.: Nieśmiata, zgrabna, tadna blondynka pozna [...]; [...] starej samotnej babie z mieszkaniem $i$ samochodem potrzeba ciepta, pocieszenia, kochanka; Michat student śmiesznawy, niezaradny pozna [...], chociaż zdarzają się szczere, jak można przypuszczać, wyznania, np.: Wrażliwa, ciepta, czasami wybuchowa pozna spokojnego, utożonego Pana; Wolny, średniego wzrostu, uparty pozna tolerancyjnq, niezależnq Paniq.

Niewątpliwe niedostatki, efekty nieudolności bywają opisywane jako nieuchronne skutki uboczne działań godnych zachwytu, np.: Miatem świadomośc, że w momencie, gdy decydowalismy się na reformy, że będzie to wiq̨zato się ze spadkiem popularności rzadu, ale odpowiedzialnośc nie tylko za dzisiejsze życie w kraju, ale także za przysztośc Polski nakazywata wykonać te reformy, bo przecież wszyscy chcemy żyć w kraju nowoczesnym, dobrze zarzadzanym, sprawnym, który daje szansę, daje szansę ludziom, którzy mieszkaja w Polsce, i to wymagato pewnej odwagi politycznej [...], a nawet jako osobliwe osiagnnięcia, np.: Nasza demokracja jest tak silna, że nawet teraz mamy rząd mniejszościowy, który wykonuje wszystkie niezbędne dziatania [...]. Jest stabilność między parlamentem $i$ rzqdem - to sie nieczesto nawet udaje w demokracjach znacznie starszych niz polska, a nam wychodzi to na dobre. To sq naprawde takie osiagnięcia, o których nie marzyliśmy dziesięć czy piętnaście lat temu.

W inseratach również zdarzają się wypowiedzi, które można interpretować jako kamuflujące informacje o wadach nadawcy, np.: Atrakcyjna, szczupla blondynka lubiaca ryzyko i zabawe pozna odpowiedniego Pana.

Niekiedy jednak treść spontanicznej wypowiedzi budzi sprzeciw, np.: Wypada mi się przyznać do pewnej stabości: lubię szkocki produkt; Lubię seks jak koń owies; Kolega powiedziat, że [...] mi się w oczach świecq takie kurwiki. To było upowszechniane przez wszystkie polskojęzyczne telewizje i komentowane: Pani postance owies do gtowy uderzyt.

W ofertach matrymonialnych postrzega się tylko niekiedy podobne zbędne wynurzenia, np.: Wdowa po przejsciach pozna wyksztatconego, mądrego, rozsadnego Pana; Przystojny, zadbany, z klasq 184/49, wyższe wyksztatcenie, wrażliwy na piękno, z gtowa do interesów, okradziony pozna [...].

Słownictwo pozytywnie wartościujące polityka określa jego cechy. Są to dodatnio nacechowane przymiotniki i imiesłowy, np.: Jestem cztoriekiem uczciwym, prostolinijnym $i[. .$.$] ; jestesmy konsekwentni, wytrwali, uparci w dq-$ $\dot{z}$ eniu do realizacji naszego programu; $[. .$.$] jestem ambitna i$ zdeterminowana [...], czasem też wskazujące negatywne cechy, których jednak kandydat jest 
pozbawiony, np.: Nie jestem drapieżna. Są także rzeczowniki nazywające autora tekstu jako posiadacza cennej cechy pozytywnej, np.: Jestem perfekcjonista; ja mam taka cechę, że wszystko, co robię, chce doprowadzić do końca. Czasowniki informują o pozytywnych zachowaniach polityka, godnych uznania czynnościach podejmowanych przez niego, np.: należe do politykórw, którzy konsekwentnie domagali się zmiany kursu gospodarczego w państwie; To, co on tutaj gtosit, to ja już mówitem co najmniej 10 lat temu. Doktadnie wszystko, co powiedziat Clinton, już powiedziatem, tylko jeszcze zgrabniej, jeszcze tadniej; [...] ja zawsze gratem dla sprawy, a nie siebie. Za te sprawy bytem nawet prezydentem. Ale za sprawy. Kiedy realizowatem sprawy, kiedy walczytem o system [...].

W anonsach spotyka się nieco inne przymiotniki określające nadawcę, np.: Przystojny kawaler [...]; 45-letnia, wolna, wyższe, niewysoka, szczupta, atrakcyjna [...]; 27-letni sympatyczny kawaler, pozna [...]; Wolna, wyksztatcona, pracująca pozna [...]. Służą one przedstawieniu pozytywnego opisu cech fizycznych (atrakcyjna, piękna, czarnowtosa, przystojny, szczupta, zgrab$n a, z a d b a n a)$, intelektualnych (wyksztatcony, rozsadny), charakterologicznych (gospodarna, odpowiedzialny, opiekuńcza, przedsiębiorcza, skromny, solidny, spokojny, tolerancyjny, uczciwy, wierny), stanu majątkowego autora (sytuowana, niezależna). Część przymiotników wskazuje cechy podlegające weryfikacji (27-letni, niewysoki, nieszczupty, czarnowtosa, puszysta), więc czasem także nieponętne, co się w tekstach propagandowych zwykle nie zdarza. Rozmaitość w ogłoszeniach matrymonialnych jest łatwo dostrzegalna. Warto zauważyć, że wiele $z$ tych przymiotników (wyksztatcony, rozsqdny, odpowiedzialny, solid$n y$, skromny, uczciwy) chciałoby się móc zastosować do deskrypcji kandydatów do funkcji publicznych. Rzeczowniki charakteryzujące eksponują weryfikowalne właściwości oferentów (blondynka, kawaler), ale i nawiązują do cech deklarowanych, niedających się zweryfikować przed ewentualnym ślubem, np.: domatorka, romantyk.

Wyrazy obcego pochodzenia, terminy specjalistyczne mają świadczyć o erudycji, o intelekcie polityka, np.: [...] w którym ze zdumieniem konstatuje, że zmniejszyto się podczas tej koalicji rozwarstwienie dochodów; [...] nie jest decyzja komfortowa i myśle, że ostatnia rzecz, no, jakq można zarzucic tej inicjatywie i osobom, które ja podjęty, to oportunizm w tej sprawie czy konformizm. $\mathrm{W}$ anonsach matrymonialnych wyrazy obce (bezpruderyjny, bizneswoman) pojawiają się raczej w funkcji referencjalnej niż ekspresywnej.

Zdarzające się słowa kolokwialne, rubaszne negatywnie prezentują członków elity politycznej, np.: Tak. To jest trudne muszę powiedzieć; ta goloneczka, ta wątróbka, ten bigosik - pociagga mnie trochę; [...] w oczach świeca takie kurwiki. W drukowanych tekstach ogłoszeń nie pojawiają się wyrazy z niskiej odmiany stylu potocznego. 


\section{Od dawna politycy chętnie stosują nacechowane emocjonalnie frazeolo-} gizmy, bo dzięki ich wieloznaczności, nieprecyzyjności mogą nie odkrywać nad miarę swoich intencji, a prezentują się jako osoby błyskotliwe, dowcipne. $\mathrm{Z}$ upodobaniem stosują zmodyfikowane połączenia wyrazowe, np.: [...] nasuwa mi się taka refleksja: tak jak dziś na Zachodzie boja się szalonych krów, czy my nie powinniśmy się obawiać szalonych polityków; tonacy brzydko się chwyta. $\mathrm{W}$ inseratach występują oczywiście frazeologizmy emocjonalnie neutralne, np.: średniego wzrostu, kultura osobista, ognisko domowe, bez natogów, przejść przez życie, godny zaufania, staty w uczuciach, zatożyć rodzine, puste stowa, życie prywatne, kobieta sukcesu, niezalė̇ny finansowo, dobrze wyksztatcony. Niektóre $\mathrm{z}$ nich są już nieco przestarzałe i dziś odczuwane jako bardzo uroczyste lub nieco pompatyczne. Modyfikację frazeologizmów obserwuje się rzadko (por.: [...] spokojny i bez zobowiązań szuka swojej drugiej potórwki). Zdarzają się cytaty $z$ tekstów literackich, poetyckich.

W wystąpieniach polityków, także poza kampaniami wyborczymi, pojawiają się wypowiedzi zawierające przejęzyczenia, deformacje frazeologizmów, błędy językowe prezentujące mówcę negatywnie, np.: Nie uważam, aby pod dachem SLD schronity się tylko orty, ee nie mniej jednak, ponieważ takie zjawiska moga zachodzic miejsce, bardzo ważny jest sposób reakcji; Chciatbym pana przewodniczacego taskawie poprosić [...]; [...] ja pracowatem w różnych sektorach rolnictwa, ja znam ciężkośc pracy; To wota o zgrozę do nieba; [...] to, co przelato szale goryczy; nie wylewaí mleka w kapieli.

Budowa tekstu obszerniejszego wystąpienia może również pozytywnie świadczyć o mówcy, jego sprawności intelektualnej i językowej, np.: Perwnie bym tego zdania nie powiedziat; z sympatii, ale pan jest dzisiaj bardzo agresywny, więc to powiem: więcej zostanie w Polsce po rzqdzie Jerzego Buzka niż po rzadzie Józefa Oleksego, jestem tego pewien; Wszyscy jestesmy dzis swiadkami pewnych roszad, przegrupowań niektórych polityków przed tymi wyborami. My jesteśmy ugrupowaniem statym, nie szukamy poprawy naszej sytuacji na scenie politycznej poprzez zmiany nazw, prezentujemy jasno nasze poglady [...]. Konstrukcje ogłoszeń są właściwie standardowe, bo o tym przesądza cennik (opłaty za słowo lub za wers) i w jakiejś mierze przyjęty wcześniej w określonej gazecie schemat. Inseraty mają zwykle 3-4 wersy, dłuższe zdarzają się rzadziej, krótsze, jednowersowe, właściwe są informacjom „o usługach towarzyskich”, np.: Dojrzata, tel. (042) 630 [...]; Figlarna studentka, O 503 [...]. I te służą autoprezentacji.

Zaburzona składnia wypowiedzi (np.: Zgadzam sie w tym sensie... $\dot{z} e$ ponieważ rzad po posiedzeniu Komitetu Integracji Europejskiej... w najbliższy piatek przedstawi petne stanowiska, przyjeżdza w przysztym tygodniu komisarz yyy, który zajmuje sie sprawami rozszerzenia yy $i$ wtedy to stanowisko będzie 
reprezentowane jednoznacznie), niedostatek dowcipu, a nadmiar złośliwości (np.: [...] gdy się mówi "platforma", to ja do końca nie wiem, co to znaczy; no, w dawnych latach platforma stużyta do przewozu wegla. Czy platforma jest bytem politycznym? Nie wiem), dają negatywne świadectwo intelektowi i sprawności językowej polityka. Rzadko obserwuje się rażące błędy (por. jednak: Chcę być szczęśliwa i dać je komuś) w przemyślanych przecież i starannie przygotowanych przed oddaniem do druku anonsach. Trafiają się niedostatki interpunkcyjne (np.: Wdowa po 50 prawnik opiekuńcza czuta mita pozna odpowiedzialnego inteligentnego Pana), co może pozostawać w związku $\mathrm{z}$ wymuszanymi przez cennik osobliwościami składniowymi.

Autoprezentacji w inseratach matrymonialnych służy również wskazywanie oczekiwań ogłoszeniodawcy. Cechy poszukiwanego partnera charakteryzują nadawcę, jego upodobania, skłonności, intencje, np.: Puszysta wdowa, 52 lata, na state w Holandii, pozna sytuowanego pana z samochodem, do lat 60; Wolny, 50-letni, dobrze wyksztatcony pozna zgrabnq, pogodnq, z temperamentem.

Niewiele pod tym względem różnią się ogłoszenia przedwyborcze. Wprawdzie nie od pojedynczego wyborcy oczekuje polityk pożądanych zachowań, ale od całej grupy połączonej podobną sytuacją materialną, wykształceniem, światopoglądem. Deklaruje swoje zainteresowania tak, by wprawdzie nikogo do siebie nie zrazić, ale by pozyskać wyborców najatrakcyjniejszych, tj. zdolnych do kształtowania opinii społecznej, a także tych, którzy występują w najliczniejszej grupie.

Kandydaci do funkcji publicznych starają się równie ponętnie zaprezentować wyborcom jak kandydaci do roli małżonków. Wprawdzie nie mówią o swoich cechach fizycznych, ale przed kamerami telewizyjnymi pokazują się staranniej niż zwykle ubrani, ufryzowani, odmłodzeni stosownym makijażem, jeśli są bardzo dojrzali, albo dowartościowani przydającymi powagi rekwizytami, np. okularami, jeśli wyglądają zbyt młodo. Poruszają się energicznie, mimiką i gestami dają odbiorcy do zrozumienia, że są fizycznie i umysłowo sprawni. W innych wizualnych reklamach przedwyborczych (ulotki, plakaty itp.) starsi politycy pokazują swoje zdjęcia sprzed kilku, kilkunastu lat. Korzystają z urządzeń służących elektronicznej obróbce obrazu i dźwięku.

Nawet atrakcyjność erotyczna bywa przez polityków sugerowana wyborcom. Pokazywanie się z partnerem (małżonkiem), z własnymi dziećmi, w otoczeniu atrakcyjnych wielbicieli (tańczących, śpiewających) bywa uzupełniane (głównie przez mężczyzn) wypowiedziami z odcieniem erotycznym (np. Prawdziwego mężczyzne poznaje się nie po tym, jak zaczyna, ale po tym, jak kończy).

Najistotniejsze dla wyborcy są te środki językowe, które obiecują spełnienie jego życiowych oczekiwań i dlatego główne przesłanie spotów przedwyborczych brzmi tak, np.: Jesteśmy po to, żeby wam pomóc. Razem możemy 
dużo więcej. Nasze wspólne pomysty i inicjatywy będq wtedy dużo skuteczniejsze. Szczegóły zależą oczywiście od podatności perswazyjnej grupy, do której są kierowane. Wprawdzie żadne ugrupowanie nie lekceważy grupy najliczniejszej, a więc osób niewykształconych, niezamożnych, niepewnych przyszłości, ale niewielu jest polityków, którzy odwołują się przede wszystkim do ludzi wystraszonych, bezradnych, bezwolnych, bo otwarte opowiadanie się po ich stronie odstręcza nie tylko średniozamożnych i bogatych, kształtujących też opinię publiczną, ale również tych biednych, którzy nie utracili jeszcze nadziei na poprawę swojego losu i nie chcą stabilizować się w roli korzystającego z zasiłków nędzarza. Poszukujący aprobaty autorzy ogłoszeń matrymonialnych podobnie oferują potencjalnemu partnerowi pewne korzyści wynikające z zawarcia związku, obiecują współdziałanie, wsparcie, pomoc, opiekę, ale nie zwracają się do osób biednych, opuszczonych, zaniedbanych, bo to mogłoby zrazić adresatów atrakcyjniejszych.

Prezentacja w mediach dokonuje się za sprawą ich pracowników. To oni decydują o porze emisji radiowych i telewizyjnych programów, w których pojawiają się osoby będące i mogące być obiektami zainteresowania publiczności (słuchaczy, widzów); obierają miejsce dla nich na stronach gazet i czasopism. Wiadomo, że są pory szczególnie korzystne, bo najwięcej osób słucha wtedy radia i ogląda telewizję, i jest strona tytułowa gazety bądź czasopisma, na której od dawna lokuje się zapowiedzi informacji najważniejszych, zdjęcia ludzi zasługujących okresowo na uwagę.

Od redakcji zależy otoczenie komunikatu, którym może być wystąpienie lub omówienie wystąpienia osoby prezentowanej. Omówienie jest wariantem zostawiającym redakcji możliwość swobodniejszej ingerencji w przekaz.Można pominąć niektóre elementy wystąpienia, inne zestawić w nieprzewidzianą nawet przez autora całość, a niekiedy i dodać wypowiedzenia niewypowiedziane. Można dokonać także wyboru fragmentów cytowanej wypowiedzi. W radiu i telewizji możliwy jest również montaż fragmentów w nową całość, ze zmianą kolejności i ewentualnie także sensu. Wchodzi tam też w rachubę modyfikowanie brzmienia głosu mówcy (np. zmiana rejestru) i wybieranie odpowiadających redakcji efektów wizualnych (ujęć twarzy, eksponowanie gestów, fragmentów stroju itp.).

Redakcyjne zabiegi mogą okazać się korzystne dla osoby lansowanej, a deprecjonować osobę niechętnie traktowaną przez redakcję. Decydujący się na pokazywanie $\mathrm{w}$ mediach powinni mieć świadomość swojej zależności od prezenterów, ale też wiedzieć, że nie jest to zależność bezwarunkowa i można ją przynajmniej ograniczać. Służyć temu może autoryzowanie publikacji prasowych i przygotowywanych przed emisją programów radiowych i telewizyjnych. Pewne możliwości zmniejszania takiej zależności ma 
też uczestnik programu transmitowanego bezpośrednio $\mathrm{w}$ trakcie realizacji. Dotyczy to m.in. efektów wizualnych (stroju, mimiki, gestykulacji), jednak przede wszystkim składników werbalnych komunikatu.

O najkorzystniejszy wygląd można zadbać przed pojawieniem się w studiu telewizyjnym, pamiętać o unikaniu niepotrzebnych grymasów, nadmiernych i monotonnych gestów, ale trudniej przygotować się na wszystkie możliwe kłopotliwe i złośliwe pytania, na napastliwy ton rozmówcy. Jest to, jak się niejednokrotnie okazywało, również możliwe. Przykłady bywały bardzo różne. Pewien minister, słysząc kłopotliwe pytanie dziennikarki, wypowiadał zdanie bez związku, choć brzmiące sensownie. Taki zwyczaj ma wielu polityków. Kiedy dziennikarka nieustępliwie zadawała kolejny raz to samo pytanie, powiedział: Czepia sie pani. Dziennikarza, który powiedział coś, co nie spodobało się rozmówcy, poseł poinformował, że za to właściwie powinien mu obić twarz. Taktownie, a bardzo dotkliwie dla narcystycznej dziennikarki, która ma zwyczaj instrumentalnie traktować zapraszanych rozmówców, zareagował pewien poseł na jej przydługi monolog, mówiąc: Zdaje się, ̇̇e ja nie jestem pani potrzebny. I wyszedł ze studia. Niefortunnie zareagowała pani minister na złośliwe pytanie wykazujące jej ignorancję, twierdząc, że w jej resorcie właśnie się pracuje nad sprawą, którą złośliwy dziennikarz wymyślił.

Rozmowa, dyskusja $\mathrm{z}$ osobą przedstawianą publiczności zdarza się $\mathrm{w}$ mediach relatywnie często. W radiach i telewizjach przeprowadzane są wywiady, transmitowane bywaja spotkania, konferencje prasowe. W prasie wypowiedzi są przytaczane, streszczane.

Wchodzi też w rachubę oddziaływanie za pomocą demonstracji scenek z udziałem celebrytów, np. wiążących się z działaniem o charakterze charytatywnym (prezenty dla dzieci w przytułku, rozdawanie żywności ubogim itp.), sportowym (biegi, gra w piłkę nożną itp.), militarnym (pojawianie się w mundurze w otoczeniu żołnierzy), korporacyjnym (pojawianie się w otoczeniu strajkujących, kontestujących, manifestujących), kulturalnym (występowanie $\mathrm{w}$ roli mecenasa). Bywają także wyzyskiwane zachowania deprecjonujące (pojawianie się w niezręcznych sytuacjach, w kompromitującym otoczeniu, np. w towarzystwie prostytutki, gangstera, łapówkarza). Prezentacja najczęściej nie obchodzi się bez udziału samego zainteresowanego nią człowieka. Także wtedy, kiedy dziennikarzowi zależy na jego kompromitacji, deprecjacji. Zwykle dla uwiarygodnienia komunikatu pokazuje się przynajmniej zdjęcie osoby, do której wiadomość się odnosi. Często pokazywana jest krótka scenka i cytowany fragment wypowiedzi wspierający koncept dziennikarza ${ }^{4}$. W prezentacji

${ }^{4}$ Zwracam na to uwagę w artykule pt. Telewizyjna manipulacja zespolona, [w:] P. Krzyżanowski, P. Nowak (red.), Jezyk w manipulacji, Lublin 2004, s. 187-199. O wyzyskiwaniu 
wykorzystuje się zatem autoprezentację, która zresztą jest zależna od mediów pośredniczących między jej autorem a odbiorcami przekazu medialnego. Obróbka elektroniczna obrazu i dźwięku daje dziennikarzowi możliwość swobodnego przetwarzania wystąpień osób ocenianych przez media.

Obiektami zainteresowań dziennikarzy często bywają politycy, artyści, uczeni, wybitni specjaliści z różnych dziedzin życia, ale też przestępcy, ofiary zbrodni, katastrof, kataklizmów. Prezentacja medialna tych ludzi bywa niekiedy zaskakująca. Zdarza się lansowanie osób niegodnych i deprecjonowanie zasługujących obiektywnie na szacunek.

\section{Bibliografia}

Bukowska M. (2006), Autoprezentacja jako forma komunikacji spotecznej, „Administracja Publiczna", nr 1, s. 336-342.

Doliński D. (2005), Techniki wptywu spotecznego, Warszawa.

Domachowski W. (1998), Przewodnik po psychologii spotecznej, Warszawa.

Dymkowski M. (2001), Autoprezentacja pozbawiona mistyfikacji a pojmowanie siebie, „Czasopismo Psychologiczne", nr 2, s. 147-154.

Karwatowska M. (2007), Potrzeba akceptacji w internetowych ogtoszeniach matrymonialnych, [w:] A. Mikołajczuk, R. Pawelec (red.), Na językoznawczych ścieżkach, Warszawa.

Kazimierowicz M. (2003), Autoprezentacja, „Nowa Szkoła”, nr 3, s. 19-21.

Klauzińska K. (2006), Autoprezentacja bezpośrednia i przewrotna, „Poradnik Językowy”, z. 6, s. $17-28$.

Królik G. (2002), Autoprezentacja, Katowice.

Królik G. (2012), Autoprezentacja, czyli jak się sprzedać pracodawcy, Katowice.

Kudra B., Sitkowska K. (2004), Autoprezentacja wybranych rozgtośni radiowych (analiza porównawcza rozgtośni PR 1 i RMF), [w:] K. Michalewski (red.), Wspótczesne odmiany jezzyka narodowego, Łódź, s. 216-224.

Kuryło E. (1996), Autoprezentacja a cel wypowiedzi, „Socjolingwistyka”, t. 15, s. 77-84.

Leary M. (1999), Wywieranie wrażenia na innych. O sztuce autoprezentacji, Gdańsk.

Michalewski K. (2004), Prezentacja i autoprezentacja polityków w telewizji, [w:] Sučasná jazyková komunikácia v interdisciplinárnych súvislostiach, Bańska Bystrzyca, s. 271-280.

Michalewski K. (2009), Komunikaty mieszane, Łódź.

Michalewski K. (red.) (2000), Regulacyjna funkcja tekstów, Eódź.

Ożóg K. (2004), Język w stużbie polityki. Jezzykowy ksztatt kampanii wyborczych, Rzeszów.

Pantalon M. V. (2011), Btyskawiczne wywieranie wptywu. Jak motywować siebie i innych do natychmiastowego dziatania?, Gdańsk.

Patterson K., Grenny J., Maxfield D. i in. (2009), Sztuka wywierania wptywu, Kraków.

cudzych wypowiedzi pisałem w artykule pt. Przytaczanie cudzych wypowiedzi jako srodek perswazji w telewizji, „Rozprawy Komisji Językowej Łódzkiego Towarzystwa Naukowego” 1999, t. 44 , s. 63-69. 
Poprawa M. (2006), Autoprezentacja w debatach polityków a zmiana telewizyjnego uktadu komunikacyjnego, „Rozprawy Komisji Językowej Wrocławskiego Towarzystwa Naukowego”, t. 32, s. 57-66.

Pstrąg J. (2007), Autoprezentacja nauczyciela, „Wychowawca”, nr 10, s. 7-10.

Sampson E. (1996), Jak tworzyć wtasny wizerunek, Warszawa.

Siemieniak P. (2008), Autoprezentacja jako forma manipulacji, „Zeszyty Naukowe Politechniki Poznańskiej. Humanistyka i Nauki Społeczne”, z. 57, s. 45-53.

Sobstyl K. (2002), Ogtoszenia towarzysko-matrymonialne w jezyku polskim i niemieckim, Lublin.

Stojanowska E. (1998), Autoprezentacja prywatna i publiczna w sytuacji powodzenia i nieporwodzenia, „Przegląd Psychologiczny”, nr 1/2, s. 165-180.

Wojtak M. (1990), Z problematyki opisu stylu tekstów użytkowych na podstawie ogtoszeń matrymonialnych, „Poradnik Językowy”, z. 2, s. 79-87. 